force of mere bodily strength. Milton finely expresses the idea when he makes his hero say:

God, when be gave me strength, to show withal

How slight the gift was, hung it in my hair.-Samson Agonistes.

The very austerity of his Nazarite vow in the matter of food and drink makes his sensuousness in the matter of lubricity all the more repugnant. He could rend a lion as easily as though it were a kid, and even in his weakness could topple down Dagon's temple. But he could not rule himself. His tragic suicide was the dread and punitive entail of his own fatuous sensuality. Here, in fact, is the grand meaning of this grotesque yet sombre story. The tragedy of Samson is a tragedy of Nemesis. Thus Samson himself is both his own riddle and his own solution :

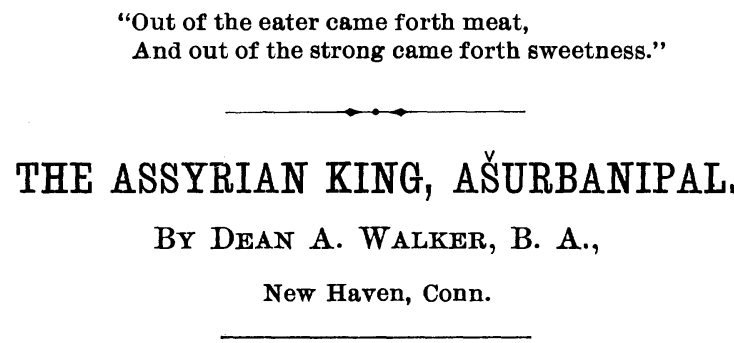

II.

Of this period, from the close of the Elamitic war till the king's death, we have very little knowledge. The king's own records of his campaigns close with the defeat of the Arabs at Damascus and the reduction of Elam to the rank of a province, about 648 or 647 B. C., and it was till lately supposed that he died about that time. This supposition was based on a statement in the Canon of Ptolemy that a certain Cinneladanus, a name quite unlike Ašurbanipal, reigned in Babylon from 647 to 626 B. C. But in his own annals, Ašurbanipal stated that after putting his brother Sa'ul-mughina to death, he himself reigned at Babylon; and Polyhistor affirms that Sa'ul-mughina was succeeded by his brother, who reigned in Babylon twenty-one years. No records of his successor are found to establish either conclusion, but it seems certain that Cinneladanus was one of several names by which he was known, either in Assyria or in Babylonia alone, and that a long period of peace followed the activities of the earlier part of his reign, in which little occurred that seemed to him worthy of record.

Such an hypothesis accords best with the wonderful advance made during this reign in the arts of peace, the evidence of which is not to be sought only in the chronicles of the time, but may be actually seen in the wonderful products remaining to us from this reign. He now had leisure for those great works for which the wars of his earlier years had furnished abundant means. This period was to Assyria what the age of Pericles was to Greece and the age of Solomon was to the Jews, and presents a much more pleasing aspect of the monarch's character. We now see him, not as a powerful and boastful warrior overrunning the territories of his weaker neighbors and glorying in the complete destruction he accomplishes, but as a patron of art and literature and a builder of magnificent edifices. 
We will not go into a detailed description of Ašurbanipal's building enterprises, but merely enumerate them and state a few characteristics. His most important work in this line is his own.great palace at Koyunjik. Beside this he made some additions and repairs on the palace of his grandfather Sennacherib, also at Koyunjik. He built several temples, two of which were for the Goddess Ištar at Nineveh and Arbela, and repaired many others. $\mathrm{He}$ is said by some Greek historians to have built the cities of Tarsus in Cilicia and Anchialus, but it is elsewhere claimed that Tarsus was built by Sennacherib.

The great palace of Ašurbanipal is one of the largest of Assyrian buildings, but is chiefly noteworthy for its peculiar plan, its wealth of ornamentation, and the beauty and delicacy of its sculptures. The common plan of Assyrian palaces is rectangular, but in Ašurbanipal's palace the main building is shaped like the capital letter $T$. It is to the sculptures and bas-reliefs in this building that we are mainly indebted for our knowledge of the private character of the king. Assyrian sculpture, as a rule, takes little notice of the common people except as they are brought into direct connection with the king, but in the palace of Asurbanipal we find much attention given to portraying scenes of every-day life, as well as of battles and the hunting sports of the monarch. We can only attribute this to an interest on the part of the king in his people and in the state of business and the arts in his kingdom. It is true that many of these scenes may be intended merely to show how the royal table was supplied with the delicacies in which the royal palate delighted, as in the fishing scenes and where servants are bringing in hares and partridges; but previous rulers had been content to eat what was set before them, asking no questions. Ašurbanipal must have portrayed on the walls of his dining room the methods by which these things were set before him.

Ašurbanipal was interested in the works of nature. In his sculptures are found beautiful garden and river scenes, in which the backgrounds are filled out with all things appropriate, as birds in the air, fish in the waters and fruit on vines and trees, many of which are carved with great delicacy. Whether it can be said of him as of King Solomon that he "spake of trees from the cedar tree that is in Lebanon even unto the hyssop that springeth out of the wall; he spake also of beasts and of fowl and of creeping things and of fishes," it is at least evident that he was interested in them and had their species to some extent distinguished in his sculptures. The study of these sculptures is therefore no small aid in the interpretation of the tablets left us from this period, in which lists are drawn up of the principal objects of the animal and vegetable kingdoms as known to the Assyrians. These lists are very complete and show some attempt at scientific classification. Whether this implies any scientific study on the part of the king himself may be questioned; but it is reasonable to infer from it that the study of science was favored at his court; for in an absolute and despotic monarchy like that of Assyria, all life, social, commercial, literary and scientific, centers about the king. What he favors prospers, and what he neglects languishes.

The same question arises, and is probably to be answered in the same way, as to Asurbanipal's literary character. The Assyrians were not a literary people. They were a race of warriors, and their inscriptions up to this period were confined to records of the monarch's wars or of his displays of wealth in the construction or repair of palaces, or of his piety in temple building. But in this 
reign, there was a remarkable birth of interest in literature, and as is usual in such a renaissance, a revival or marked advance in the arts and sciences. Even the dry records of campaigns begin to show a literary style. Our most important evidence of this is the great library of Asurbanibal, brought to light by Mr. Layard and afterward further explored by Mr. George Smith. In one of the halls of Sennacherib's palace at Koyunjik, the floor was found covered to the depth of a foot or more with the clay tablets of this library, many of them in very mutilated condition and seeming to have fallen from their shelves or other resting places when the palace was destroyed. The inscriptions on these tablets were estimated by Mr. Layard to exceed in amount all that the monuments of Egypt have to offer, and cover almost every department of human thought, commerce, art, architecture, zoology, botany, geography, astronomy and chronology, law, ethics and religion, as well as purely literary productions. Under the head of commerce, we have contract tablets of many kinds, records of loans and sales, from which it may yet be possible to construct a political economy of ancient Mesopotamia. Among these are the complete records of the banking firm of Egibi, presenting the minutest details of business. Under natural science, we have the lists of animals and plants and of the heavenly bodies; in geography, lists of nations and places; there are grammars and vocabularies and bi-lingual lexicons, designed to preserve the language and make available the records of an older civilization; in the department of ethics, religion and general literature, we find psalms and hymns, lists and genealogies of the gods with their descriptive epithets, calendars of sacred days with directions for their proper observances, and epic poems and legends of the gods and early history of the world. Most interesting among these is the series of twelve tablets containing the legend of Isdubar, including the creation and deluge tablets which so closely resemble the biblical accounts, and the descent of Ištar into Hades, reminding us of the Greek legend of Orpheus and Eurydice.

Most of these religious and literary tablets are copies of older works, as is proved by the frequent lacunae in them at places where the originals were mutilated or obscure. These originals doubtless came from Babylonia, and may first have attracted Ašurbanipal's interest on his invasion of that province to punish his rebellious brother. He must there have been struck with many novel ideas, and as prominent among them, with the contrast between Babylonia and Assyria in the affairs of religion. Babylonia was the ancient seat of their common religion, and the worship of the gods and the study of religion were there carried on to a degree unknown in Assyria. In the latter country, the temple was a mere attachment to the palace; but in Babylonia, it stood alone, and in several instances by its strength and weight has withstood the wear of time to this day, while the palaces are crumbled to dust. In Assyria we find no traces of ancient graves; while in Babylonia, vast cities of the dead, with well ordered streets and careful system of drainage and other provisions for the comfort of the dead, prove that to them the future life was as real as the present and the unseen world engaged a large share of their thought. Ašurbanipal's long reign in Babylon gave him ample time to acquaint himself with these interesting peculiarities of that country. Something of these thoughts he must have brought to Assyria, and had his dynasty been granted a longer period of power, the studies thus inaugurated might materially have changed the character of his people. But for this, the work was begun too late. Soon after Ašurbanipal's death, Nineveh was destroyed 
by the Medes, and the magnificent library he had collected was buried in the ruins of the palace, there to be preserved two thousand years for our edification.

For Asurpanipal's religious character we go to bis own records. In these he everywhere styles himself the servant and favorite of the gods; and acknowledges their hand in all his successes. He regards himself as divinely appointed to make known their power to the nations round about. He is very ready to undertake these missionary enterprises, and once undertaken, he makes very thorough work of it. The enemies of Assyria are the enemies of Ašur and have insulted his power. These insults he, Ašurbanipal, is to punish, and it is his work to restore the gods to their former dignity. Thus in his conquest of Elam, he recovers and restores to her proper temple in Babylonia, to her great satisfaction, the goddess whom Kudurnanhundi, the father(?) of Chedorlaomer of Biblical fame, had carried away 1635 years before. Where enterprises of this kind, however, are so directly in the line of bis private and political interests, it is difficult to say just how much we are to credit to personal piety. Ašurbanipal seems to have done little in temple building, only four such works being ascribed to him, whereas his father, Esarhaddon, built as many as thirty-six in his short reign of twelve years. But he was active in repairing many that had become ruined, and furnished both new and old most lavishly with statues of the gods and furniture of gold, silver, and rare kinds of wood.

The character of Ašurbanipal furnishes but another proof in history that devotion to religion and the fine arts may go hand in hand with great cruelty of disposition. None of the kings of Assyria can be called merciful; but Sennacherib and Esarhaddon had been comparatively mild in their treatment of their prisoners. Ašurbanipal in this respect took a backward step and imitated the deeds of the most cruel kings before him. In his earlier years he seems to have been more lenient. Necho and his fellow conspirators in Egypt were forgiven and restored to positions of power. Baal, perhaps for political reasons, was retained on the throne of Tyre. But in his later years, those that fell into his hands were put to death, and often with severest tortures. Mutilation was a common form of punishment. On the second defeat of the Elamites, their leaders experienced most cruel treatment. The grandsons of Merodach-baladan were mutilated, two of the allied princes had their tongues torn out, two of Teminumman's officers were flayed alive.

These and other cruel forms of torture we find not only recorded in exultant language in the inscriptions but portrayed also on the walls of the palaces. There we see pinioned captives led about by rings passed through the tongue or lips, and condemned men are buffeted in the face before being executed, or are led about the city with the heads of their friends hung about their necks.

Much of this cruelty, however, is to be pardoned to the customs of a rude age, and numerous parallels to it may be found in all the nations of that day. Asurbanipal's cruelty was not the result of any meanness of character, like that of the coward who seeks by display of power over his inferiors to console himself for his enforced subservience to his superiors. It was, rather, due to the excess of animal spirits in the man and to his pride of station, which made insignificant the life and comfort of the common lot of men. It was often exercised for dramatic effect, to inspire his enemies with the sense of his power. It was akin to the old Roman's delight in gladiatorial sports, whose familiarity with suffering and blood in constant warfare hardened the heart to feelings of pity at other times. 
It was with this same excess of animal spirits that Ašurbanipal enjoyed the sports of the chase. In these he found exercise for his splendid physical powers and daring courage. He shrank from no personal danger. Unfortunately we have no biography of him by contemporary and unprejudiced writers; but if we may credit his own statements, he was a marvel of strength and courage, of unerring aim with bow and spear, ready single handed and on foot to encounter the king of beasts and despatch him with a thrust of the short-sword. The calm dignity and ease with which his royal highness grasps the wounded and infuriated lion by the forelock or beard and drives the dagger between his ribs entitles him to a place in the tales of the Arabian Nights. In the bas-reliefs the king stands perfectly erect and at his ease, while the lion, whose dead-weight would be four times the king's avoirdupois, leans against him at an angle of forty-five degrees, without in the least disturbing his equilibrium. The sculptures representing such astonishing prowess have not always the courage to face our incredulity single handed. One of them, at least, is backed by an attendant in the shape of an inscription to the following effect: "I, Ašurbanipal, king of the nations, king of Assyria, in my great courage fighting on foot with a lion, terrible for his size, seized him by the ear, and in the name of Ašur and Ištar, goddess of war, with the spear that was in my hand, I terminated his life."

However much allowance we may think it necessary to make for the ego in such a passage as this, we cannot doubt that Asurbanipal was a man of great physical courage in war and the chase, and possessed many noble qualities of mind befitting his high station. In almost every respect, as we now know him through the inscriptions so recently brought to light, he stands at the farthest remove from that character with whom he has so long been identified, the effeminate Sardanapalus of the Greek historians. The latter was renowned for his wealth, but was a weak and inefficient ruler, devoted to the pleasures of the harem and seldom setting foot outside his palace. Ašurbanipal, too, possessed great wealth, but he did not allow himself to become enfeebled by luxury; and although his practice of taking as wives and concubines the daughters of subject princes gave him a large harem, he did not lose his fondness for manly sports and recreations either bodily or mental.

In a despotic eastern monarchy, where the character of the people is more directly dependent on the character of the ruler than under a freer form of government, the king may be judged somewhat by the state of the nation. On this test, Ašurbanipal must be given a high place among the rulers of that age. In his reign, the kingdom attained its greatest territorial extent, Assyrian art reached its highest development, and science and literature, probably for the first time in that nation, were seriously cultivated. It is this last form of activity that more than anything else places Asurbanipal above his predecessors, and entitles him to lasting fame and gratitude. The gathering of his great library, involving as it did the copying and translation of so much that was then old, as well as the production of much new material, has opened to us the doorway to a civilization far more ancient even than his own time. It may be that, as the contents of this library become better known, some Ebers in the field of Assyriology will find material from which to picture for us the home life of Terah and Nahor in ancient Ur of the Chaldees before the first great Pilgrim Father "gat him out of his country and from his kindred and from his father's house to go unto the land that the Lord would show him." 
History is being added to at both ends. It is lengthening out toward the future, but it is also reaching back into the past. The monuments of Assyria, Babylonia and Egypt, the Moabite Stone and the Hittite inscriptions invite us to retrace the long journey that the human race has made since it left its primitive home in Eden and to explore those regions of history so long forgotten. Those that have burned the midnight oil in the toilsome endeavor to master the cuneiform signs are sometimes tempted to feel that all the information they can get out of them is fairly earned and they have only themselves to thank for it; but we should not forget our indebtedness to Ašurbanipal and other scholars of antiquity, who have gathered such vast amount of material for our study, who have filled with such rich treasures the fields in which we are now so eagerly plying the spade.

\title{
OLD TESTAMENT WORD-STUDIES: 3. MORAL GO0D.
}

\author{
By Rev. P. A. NoRdell, D. D.,
}

New London, Conn.

In the following group of words the general conception of moral good is made sufficiently comprehensive to include terms which a more rigid classification would place in other categories. It is to be understood simply as a convenient phrase under which a number of words, very prominent in Old Testament usage, may be gathered together for brief consideration.

\section{Qádhăsh to be holy.}

The primary meaning of $q \bar{a} \mathrm{dh} \breve{\mathrm{a}} \mathrm{sh}$ has been much disputed. Many writers have connected it with $\mathrm{h}_{\bar{a}} \overline{\mathrm{dh}} \mathrm{a} \mathrm{sh}$ to be new, to come to light. as the new moon, and have inferred that originally it meant to be light from the very first, hence pure, untarnished, splendid. This derivation seems to find support in the fact that the conception of the divine holiness is so often associated with that of the divine glory; "[The tabernacle] shall be sanctified by my glory," Exod. 29:43. "Holy, holy, holy is the Lord of Hosts ; the whole earth is full of his glory," Isa. 6:3. "Light is the earthly reflection of God's holy nature; the Holy One of Israel is the Light of Israel (Isa. 10:17). The light with its purity and splendor is the most suitable earthly element to represent the brilliant and spotless purity of the Holy One in whom there is no interchange of light and darkness." (Keil on Exod., p. 29.) This derivation, however plausible, has been almost wholly abandoned by recent writers, who refer $q \bar{a} d h a ̆ s h$ to a root $q d$ to cut, sever, hence to separate. This seems to be the sense in which the word is employed in in respect to Jeremiah's divine appointment to his prophetic work, "Before thou camest forth from the womb, I separated thee; I have appointed thee a prophet to the nations," Jer. 1:5. Separation involved a two-fold idea; that of separation from the common mass, from imperfection, impurity, and sin, and of separation or dedication to some specific work, person, or deity. It may be a little difficult to realize the original simplicity of this idea of holiness, expressing, as Wellhausen says, "rather what a thing is not, than what it is ;" but from this meager foundation has been developed a series of the most pregnant significations in the whole range of Old Testament revelation. 